\title{
Evaluation of Selected Dietary Probiotics on Growth Performance, Nutrient Utilization and Body Carcass Composition of Mystus Cavasius (Hamilton, 1822) Fry
}

\author{
Md. Zulfikar Ali ${ }^{1}$, Mritunjoy Paul ${ }^{2}$, Prasanta Jana ${ }^{2}$, Md. Khalilur Rahman ${ }^{1}$ and \\ Yahia Mahmud $^{1}$ \\ ${ }^{1}$ Bangladesh Fisheries Research Institute, Mymensingh-2201, Bangladesh \\ ${ }^{2}$ Fish Nutrition, Biochemistry \& Physiology Division, ICAR-Central Institute of Fisheries \\ Education, Mumbai-400061, India \\ *Corresponding author
}

\begin{tabular}{|l|}
\hline Ke y w o r d s \\
Mystus cavasius, \\
Probiotics, Growth \\
performance, \\
Nutrient utilization, \\
Carcass \\
composition.
\end{tabular}

A B S T R A C T

A 60 days experiment was conducted in lab conditions to evaluate the potentiality of selected probiotics on growth performance, feed efficiency and nutrient utilization to develop cost-effective quality feed for Mystus cavasius. The uniform size fry (average weight $1.05 \pm 0.04 \mathrm{~g}$ ) were randomly distributed in five experimental groups into triplicates in a series of cylindrical fiberglass tank (70L each) containing 50 fishes each following completely randomized design (CRD). Five iso-nitrogenous (CP 32\%) and iso-caloric (GE $366 \mathrm{Kcal} / 100 \mathrm{~g}$ ) experimental diets were formulated by selecting four types of probiotics: Bactocell (Pediococcus acidilactici) as T1, Bacillus subtilis as T2, Levucell (Saccharomyces cerevisiae) as T3, Mixture of above three stains as T4 and a control diet with no probiotics. The fishes were fed thrice a day at a rate of $12-6 \%$ of their body weight. At the end of the feeding trial, highest net weight gain, percentage weight gain, specific growth rate (SGR), feed conversion efficiency (FCE) and protein efficiency ratio (PER) were observed $(\mathrm{P}<0.05)$ in the $\mathrm{T} 1$ group. FCR was lowest in $\mathrm{T} 1$ group $(\mathrm{P}<0.05)$ which was significantly different from other groups except T2 group. The proximate carcass composition differs significantly $(\mathrm{P}<0.05)$ among different experimental groups. These results clearly suggest that the inclusion of Bactocell (Pediococcus acidilactici) as probiotic at $0.05 \%$ level can improve growth performance, nutrient utilization and feed efficiency in $M$. cavasius fry.

\section{Introduction}

Aquafeed accounts for about $50-60 \%$ of the variable operating costs in an aquaculture production cycle where proper nutrition is mandatory to produce an economically affordable, healthy, safe, and a high-quality product. Intensive aquaculture practices involved using high-quality protein feeds along with other essential nutrients and complementary additives to keep organisms healthy and result in good growth 
performance. Aquaculture industry in Bangladesh is faced with major challenges of inadequate supply and high cost of quality fish feeds. Commercial fish feed usually contains good quality fish meal as the major protein source, ranging from 30-50\% (Hardy, 1995). Beside the problem of high cost of commercial fish feeds, quality of seed and disease outbreak are major challenges in Gangetic catfish (Mystus cavasius) farming in Bangladesh. Use of antibiotics in culture system had been frequent to enhance growth and/or disease resistance of cultured species. Banning the use of antibiotics as growth promoters in aquaculture system as because of the potential generation of antibiotic-resistant bacterial strain, the presence of antibiotic residues in food production, the destruction of microbial populations in the culture environment and the suppression of the immune system of the aquatic animal (Sapkota et al., 2008). This criticized the most about the use of these chemical substances to stimulate growth and treat bacterial diseases in animal industries. Efforts are still being made to develop new alternative or supplementary methods to improve health of cultured species. Various studies showed that performance of the farmed fish might be elevated by using feed additives and nutraceuticals such as aromatic plant extracts or phytobiotics including spices, digestive enzymes and probiotics. Spice and natural herbs such as marjoram, basil, licorice root, black seed and peppermint have been shown to be beneficial as reported by El-Dakar et al. (2004). Functional additive or nutraceutical, like probiotics, is a potential concept in aquaculture (Li and Gatlin III, 2004) where the additions of microorganisms on diets show a positive effect on growth caused by the best use of nutrients (carbohydrates and protein) and in immunity by competitively excluding gm -ve pathogenic microorganisms from the gut of the fish (Fuller, 1989). Probiotics were originally incorporate into feed to increase the animal's growth performance and improve its immunity by increasing its resistance to diseases (Fuller, 1992). The uses of probiotic have been studied most extensively in pigs (Denev, 2008). Probiotic, which are live microbial supplements or their revivable spores, provides health benefit to the host and added in feed as dietary supplements as a means of disease control. Studies have been focused on increasing growth performance of fish (Marzouk et al., 2008) as well as physiological and immune responses of fish by feeding them with probiotic supplements (Marzouk et al., 2008). The Food and Agricultural Organization (FAO) have stated that there is potential for probiotic foods to provide health benefits and that specific strain is safe for human use (Reid et al., 2003).

The Gangetic catfish, Mystus cavasius (gulsha) is a promising species for both monoculture and polyculture practices by virtue of its air-breathing characteristics and widely distributed throughout Indo-PakBangladesh sub-continent. Among the airbreathing catfishes, Gangetic catfish, Mystus cavasius (gulsha) is very popular and high priced fish in Bangladesh. The fish has a high marketability due to its superior nutritive value, delicious taste on is cultured extensively. But culture of $M$. cavasius (gulsha) has not yet been flourished in Bangladesh due to lack of appropriate culture technology and non-availability of costeffective quality supplementary feed for the fish. Presently, intensive culture of $M$. cavasius (gulsha) is getting momentum. But farmers are facing problem with the high price of the commercial pelleted feeds. Because of the high price of feed, the profit margins of the farmers are being decreased day by day. Therefore, efforts are needed to develop a suitable quality diet for profitable $M$. cavasius (gulsha) culture. This study has been designed to evaluate the effect of selected probiotics on growth performance, feed conversion, nutrient 
utilization and body carcass composition in $M$. cavasius (gulsha) fry.

\section{Materials and Methods}

\section{Experimental procedure and design}

The feeding trial was carried out a series of cylindrical fiberglass tanks (70-L each) for 60 days at Freshwater Station, Bangladesh Fisheries Research Institute. The same aged uniform size fry of $M$. cavasius (gulsha) distributed into groups of 50 fish (averaging $1.05 \pm 0.04 \mathrm{~g}$ ) per 70 -L fiberglass tank and three replicate tanks used for each test diet following completely randomized design (CRD). Artificial aeration used to maintain an adequate level of dissolved oxygen in each test tank. The fishes were weighed at the start and end of the experiment by weekly. Weekly samplings of fish were done to adjust the daily feed ration for the following week. Water quality parameters such as temperature, $\mathrm{pH}$, dissolved oxygen, ammonia-N, nitrite-N, nitrate- $\mathrm{N}$ were monitored through weekly sampling.

\section{Experimental animals}

One thousand fry of $M$. cavasius (gulsha) were procured from Authentic Fish Hatchery, Mymensingh and acclimatized for fifteen days in the Wet Laboratory, Freshwater station of Bangladesh Fisheries Research Institute.

\section{Experimental feeds and feeding}

Five iso-nitrogenous (32\% crude protein) and iso-energetic $(366 \mathrm{Kcal} / 100 \mathrm{~g})$ experimental diets were formulated (Table 1) prior to start of the experiment. Feeds were prepared using locally available fish feed ingredients such as fish meal, meat and bone meal, mustard oil cake and rice bran in different combinations. Alpha-cellulose used as filler and carboxymethyl cellulose used as a binder at a rate of $2 \%$. Vitamin and mineral premix (Mega Vit Aqua, Novartis) added at a rate of $0.20 \%$. The selected four types of probiotics: (i) Bactocell (lactic acid producing bacteria, (Pediococcus acidilactici); (ii) Bacillus subtilis; (iii) Levucell (yeast, Saccharomyces cerevisiae) and (iv) Mixture of above stains (Pediococcus acidilactici + Bacillus subtilis + Saccharomyces cerevisiae) were added the diets following the recommended dose by the manufacturers. A control diet prepared with same feed ingredients without mixing any probiotics in each study. The all required amount of ingredients along with probiotics, vitamin and mineral premix were weighed as per formulae of experimental diets and mixed homogenously. Adequate amount of water was added to moisten the mixture to get a definite dough texture and then the mixture was extruded through $1 \mathrm{~mm}$ diameter die of a pellet machine (Hobart mixture machine, Model A200). The resultant feeds were then broken into smaller pieces and then sun dried. The pellets were made into bite size to be suitable for the fish. The experimental diets were separately packed in air-tight polyethylene bag and stored in a deep freeze for further use. Each dietary treatment conducted in triplicate tanks. The fishes were offered the experimental and control diets, 2-3 times daily at the rate of $12-6 \%$ of their body weight and sub-divided into 2-3 equal feeds at $9.00,13.30$ and $18.00 \mathrm{~h}$. Feeding rate was adjusted based on weekly sampling weights of fish.

\section{Analytical methods}

Experimental diet and fish carcass samples were analyzed for proximate composition by employing 'AOAC' procedures (AOAC, 2005). The water sample were analyzed for parameters like temperature, dissolved oxygen, $\mathrm{pH}$, free carbon dioxide, total hardness, ammonia- $\mathrm{N}$, nitrite- $\mathrm{N}$ and nitrate- $\mathrm{N}$ levels following 'APHA' procedures (APHA, 
2005). Gross energy of the experimental diet was determined using an Automatic Oxygen Bomb Calorimeter (Gallenkamp \& Co Ltd., England). Specific growth rate (SGR), $\%$ weights gain, feed conversion ratio (FCR), feed conversion efficiency (FCE) protein efficiency ratio (PER) calculated as follows:

Net gain $(\mathrm{g})=$ Final body weight $(\mathrm{g})$ - Initial body weight $(\mathrm{g})$

SGR $(\% /$ day $)=[($ Ln. Final body weight $(\mathrm{g})-$ Ln. Initial body weight $(\mathrm{g})) /$ days $\times 100$ ]

$\%$ Weight gain $=[($ Final body weight $(\mathrm{g})-$ Initial body weight $(\mathrm{g}) /$ Initial body weight $(\mathrm{g})]$ $\times 100$

FCR $=$ Feed fed $(\mathrm{g}$ dry weight $) /$ Live weight gain $(\mathrm{g})$

$\mathrm{FCE}=1 / \mathrm{FCR}$

PER = Live weight gain $(\mathrm{g}) /$ Crude protein fed (g dry weight)

\section{Analysis of data}

The statistical analysis was carried out by using statistical software package SPSS (21.0 for Windows). One way ANOVA and Duncan's multiple range tests (Duncan, 1955) were used to determine the significant differences between the means. Comparisons were made at the $5 \%$ probability level.

\section{Results and Discussion}

Optimum water quality parameters were provided to the experimental animals throughout the whole period shown in Table 2. Proximate compositions of the experimental diets (\% DM basis) shown in Table 3. Estimated crude protein and ether extract level of the experimental diets were $32 \%$ and $10 \%$. Gross energy value of the experimental diets was $366 \mathrm{Kcal} / 100 \mathrm{~g}$. Growth responses, feed conversion and nutrient utilisation of fish fed the experimental diets are shown in Table 4 and Figures 1, 2, 3, 4, 5 and 6 respectively. Growth performances in terms of weight gain, \%weight gain and SGR of fishes of T1 group was significantly higher $(\mathrm{P}<0.05)$ than other groups. Improved feed conversion ratio (FCR) was observed in probiotics fed diets. Significantly ( $\mathrm{P}<0.05)$ lowest FCR observed in $\mathrm{T} 1$ group.

Protein efficiency ratio (PER) value ranged between 1.98 and 2.50 with control diet producing significantly $(\mathrm{P}<0.05)$ lowest PER values. The significantly higher $(\mathrm{P}<0.05) \mathrm{PER}$ value was obtained in T1 group where fishes were fed with probiotics Bactocell.

The proximate carcass composition (\% wet weight basis) of the fishes at end of the experimental period is presented in Table 5. The carcass crude protein content of the fishes fed with different experimental diets ranged between $14.89 \%$ and $15.68 \%$ while carcass crude lipid content of the fishes ranged between $3.20 \%$ and $3.95 \%$. The final carcass composition of $M$. cavasius fry of different experimental differ significantly $(\mathrm{P}<0.05)$ among the groups fed with different selected probiotics with highest values observed in $\mathrm{T} 1$ group. But there was no significant difference $(\mathrm{P}>0.05)$ found between T2 and T3 group.

Optimum water quality parameters were provided during the whole experimental period which was within acceptable range of fish culture as reported by Banerjee (1967). The results of the present study revealed that the selected probiotics had significant effect on growth performance (in terms of weight gain, percent weight gain and specific growth rate) feed and nutrient utilization of $M$. cavasius (gulsha) fry. Probiotics are known as living microbial cells that promote the health of their host by improving the balance of the 
intestinal microbial flora (Fuller, 1989). Recently, it became known in aquaculture that probiotics in diets could help to improve fish growth and the culture environment in which it is reared (biocontrol and bioremediation). In the present study, significantly better ( $\mathrm{P}$ $<0.05)$ growth performance and specific growth rate (SGR) were observed in fishes of T1 group than the other experimental groups. Similar observations have been reported on Clarias gariepinus (Al-Dohail et al., 2009; Ayoola et al., 2013), Labeo rohita (Mohamed et al., 2007) and Dicentrarchus labrax (Carnevali et al., 2006). They reported that growth performance in the fishes were significantly $(\mathrm{P}<0.05)$ better in the treated groups than the control when probiotics used as feed additives in their formulated diets. This gives an indication of an improvement in the health and growth performance of fish despite the differences in the methods and species used from the present study. The improvement in growth may, however, be related to the improvement in the intestinal microbial flora $\backslash$ balance as reported by Fuller (1989).

The study results also shows that feed conversion ratio (FCR) were significantly $(\mathrm{P}$ $<0.05)$ lower in fishes of $\mathrm{T} 1$ group fed with probiotics Bactocell compared with the other groups. The results are in agreement with the findings on Nile tilapia (Lara-Flores et al., 2003; Mohamed et al., 2007), African cat fish (Al-Dohail et al., 2009; Ayoola et al., 2013) and common carp (Noh et al., 1994; Yanbo and Zirong, 2006).

Protein utilization, measured in terms of PER, in the study increased to some extent with probiotics-supplement diets with highest ( $\mathrm{P}$ $<0.05$ ) observed in T1 group. The PER values also indicated the gain in the body protein per unit protein, serves as a criterion for evaluating dietary protein of different composition (Hepher, 1988). Significantly higher $(\mathrm{P}<0.05)$ PER was recorded in fish maintained on the probiotic Bactocell supplemented diets than the other groups in the present feeding trial, corroborating the results of other previous studies. This results also agree with those obtained from previous studies by other authors (Lara-Flores et al., 2003), where growth, PER was reported to be better in Nile Tilapia fed diets supplemented with probiotics than those fed a diet without probiotics supplementation. Similar observations have been reported on African cat fish (Al-Dohail et al., 2009; Ayoola et al., 2013). Fishes of T1 group showed an improvement in growth performance, feed and protein efficiency could be due to better nutrient digestibility, high-quality absorption and increased enzyme activities caused by a proper balance of the intestinal microbial flora (Fuller, 1989) or exoenzyme secretion as suggested by Moriarty (1996). The author reported that bacteria of the genus Lactobacillus secrete a wide range of exoenzymes that aid in nutrient digestibility. Similarly, Suzer et al. (2008), Tovar-Ramirez et. al., (2004) and Wang and Zirong (2006) all reported that digestive enzyme activities were increased when fish was fed with a probioticsupplemented diet. Additionally, better growth performance and nutrient efficiency could possibly be related to lower stressor levels in fish fed the probiotics diet. It has been suggested that probiotics have a beneficial effect on the digestive processes of aquatic animals because probiotic strains synthesize extracellular enzymes such as proteases, amylases, and lipases as well as provide growth factors such as vitamins, fatty acids, and amino acids (Balcazar et al. 2006). Therefore, nutrients are absorbed more efficiently when the feed is supplemented with probiotics (Wang and Zirong, 2006)

The final carcass composition of $M$. cavasius (gulsha) fry of different experimental differ significantly $(\mathrm{P}<0.05)$ among the groups fed with different selected probiotics. 
Table.1 Formulation of the experimental diets (\% dry weight basis) for Mystus cavasius fry

\begin{tabular}{|c|c|c|c|c|c|}
\hline Treatments & $\begin{array}{c}\text { C } \\
\text { (Control) }\end{array}$ & $\begin{array}{c}\text { T1 } \\
\text { (Bactocell) }\end{array}$ & $\begin{array}{c}\text { T2 } \\
\text { (Bacillus) }\end{array}$ & $\begin{array}{c}\text { T3 } \\
\text { (Levucell) }\end{array}$ & $\begin{array}{c}\text { T4 } \\
\text { (Mixture 3) }\end{array}$ \\
\hline Ingredients: & \multicolumn{5}{|l}{} \\
\hline Fishmeal (Indonesia) & 33.00 & 33.00 & 33.00 & 33.00 & 33.00 \\
\hline Meat \& Bone Meal & 15.00 & 15.00 & 15.00 & 15.00 & 15.00 \\
\hline Mustard Oil Cake & 12.00 & 12.00 & 12.00 & 12.00 & 12.00 \\
\hline Rich Bran (auto) & 22.00 & 22.00 & 22.00 & 22.00 & 22.00 \\
\hline Starch & 12.80 & 12.75 & 12.75 & 12.75 & 12.75 \\
\hline Binder (CMC) & 2.00 & 2.00 & 2.00 & 2.00 & 2.00 \\
\hline Alpha Cellulose & 3.00 & 3.00 & 3.00 & 3.00 & 3.00 \\
\hline Vit-Min Premix* & 0.20 & 0.20 & 0.20 & 0.20 & 0.20 \\
\hline $\begin{array}{c}\text { Probiotics } \\
\text { (Diets T1-T4) }\end{array}$ & - & 0.05 & 0.05 & 0.05 & 0.05 \\
\hline C & & & & & \\
\hline
\end{tabular}

CMC - Carboxy methyl cellulose

Control with no probiotics, T1 with $0.05 \%$ Bactocell, T2 with $0.05 \%$ Bacillus, T3 with $0.05 \%$ Levucell, T4 with $0.05 \%$ mixture of all three probiotics.

*Vit-Min premix Composition of vitamin mineral premix (quantity/kg) Vitamin A, 55,00,000 IU; Vitamin D3, 11,00,000 IU; Vitamin B2, 2,000mg; Vitamin E, 750mg; Vitamin K, 1,000mg; Vitamin B6, 1,000mg; Vitamin B12, 6mg; Calcium Pantothenate, 2500mg; Nicotinamide, 10g; Choline Chloride, 150g; Mn, 27,000mg; I, 1,000mg; Fe, 7,500mg; Zn, 5,000mg; Cu, 2,000 mg; Co, 450mg, L-Lysine, 10g; DL-Methionine, 10g; Selenium, 125mg.

Table.2 Water quality parameters of experimental groups during the experimental period

\begin{tabular}{|l|c|c|c|c|c|}
\hline Parameters & Control & $\mathrm{T} 1$ & $\mathrm{~T} 2$ & $\mathrm{~T} 3$ & $\mathrm{~T} 4$ \\
\hline Temperature $\left({ }^{\circ} \mathrm{C}\right)$ & $25.9-31.8$ & $25.5-31.5$ & $25.2-31.7$ & $25.9-32.2$ & $24.8-31.5$ \\
\hline $\mathrm{pH}$ & $7.6-8.0$ & $7.8-7.9$ & $7.6-7.7$ & $7.6-7.9$ & $7.8-8.1$ \\
\hline Dissolved $\mathrm{O}_{2}\left(\mathrm{mg} \mathrm{L}^{-1}\right)$ & $6.6-7.0$ & $6.4-6.7$ & $6.3-6.8$ & $6.6-7.1$ & $6.3-6.5$ \\
\hline Free $\mathrm{CO}_{2}\left(\mathrm{mg} \mathrm{L}^{-1}\right)$ & $1.2-1.3$ & $1.1--1.2$ & $1.1-1.3$ & $1.1-1.2$ & $1.2-1.3$ \\
\hline Hardness $\left(\mathrm{mg} \mathrm{L}^{-1}\right)$ & $238-251$ & $239-246$ & $233-240$ & $238-249$ & $239-245$ \\
\hline Ammonia-N $\left(\mathrm{mg} \mathrm{L}^{-1}\right)$ & $0.04-0.06$ & $0.05-0.07$ & $0.07-0.08$ & $0.06-0.08$ & $0.05-0.08$ \\
\hline Nitrite-N $\left(\mathrm{mg} \mathrm{L}^{-1}\right)$ & $0.001-0.003$ & $0.001-$ & $0.002-$ & $0.003-0.005$ & $0.001-$ \\
\hline Nitrate- $\mathrm{N}\left(\mathrm{mg} \mathrm{L}^{-1}\right)$ & & 0.002 & 0.005 & & 0.002 \\
\hline
\end{tabular}


Table.3 Proximate composition of the experimental diets (\% dry weight basis) for Mystus cavasius fry

\begin{tabular}{|l|c|c|c|c|c|}
\hline Treatments & $\begin{array}{c}\text { C } \\
(\text { Control) }\end{array}$ & $\begin{array}{c}\text { T1 } \\
\text { (Bactocell) }\end{array}$ & $\begin{array}{c}\text { T2 } \\
\text { (Bacillus) }\end{array}$ & $\begin{array}{c}\text { T3 } \\
\text { (Levucell) }\end{array}$ & $\begin{array}{c}\text { T4 } \\
\text { (Mixture 3) }\end{array}$ \\
\hline Crude Protein (\%) & $32.15 \pm 0.21$ & $32.17 \pm 0.25$ & $32.31 \pm 0.22$ & $32.18 \pm 0.19$ & $32.25 \pm 0.22$ \\
\hline Ether Extract (\%) & $10.71 \pm 0.17$ & $10.78 \pm 0.21$ & $10.65 \pm 0.12$ & $10.79 \pm 0.19$ & $10.81 \pm 0.24$ \\
\hline Ash (\%) & $13.01 \pm 0.19$ & $13.12 \pm 0.23$ & $13.09 \pm 0.24$ & $13.17 \pm 0.17$ & $12.98 \pm 0.19$ \\
\hline Crude Fibre (\%) & $8.68 \pm 0.09$ & $8.58 \pm 0.11$ & $8.51 \pm 0.15$ & $8.66 \pm 0.14$ & $8.62 \pm 0.12$ \\
\hline NFE (\%) & $35.45 \pm 0.26$ & $35.35 \pm 0.33$ & $35.44 \pm 0.21$ & $35.21 \pm 0.29$ & $35.34 \pm 0.26$ \\
\hline GE (Kcal/100g) & $366.79 \pm 0.20$ & $367.11 \pm 0.27$ & $366.85 \pm 0.15$ & $366.67 \pm 0.31$ & $367.65 \pm 0.24$ \\
\hline
\end{tabular}

Mean values are represented as Mean standard error obtained from three replicates.

$\mathrm{NFE}=$ Nitrogen free extractives, calculated as $100-(\%$ Crude Protein $+\%$ Ether Extract $+\%$ Ash $+\%$ Crude Fibre $)$ $\mathrm{GE}=$ Gross energy content

Table.4 Growth performances and nutrient utilization of Mystus cavasius fry fed with selected probiotics for 60 days

\begin{tabular}{|l|c|c|c|c|c|}
\hline Treatments & $\begin{array}{c}\mathrm{C} \\
\text { (Control) }\end{array}$ & $\begin{array}{c}\mathrm{T} 1 \\
\text { (Bactocell) }\end{array}$ & $\begin{array}{c}\mathrm{T} 2 \\
\text { (Bacillus) }\end{array}$ & $\begin{array}{c}\mathrm{T} 3 \\
(\text { Levucell })\end{array}$ & $\begin{array}{c}\text { T4 } \\
\text { (Mixture })\end{array}$ \\
\hline Initial wt. (g) & $1.06 \pm 0.05$ & $1.05 \pm 0.04$ & $1.06 \pm 0.03$ & $1.05 \pm 0.04$ & $1.07 \pm 0.03$ \\
\hline Final wt. (g) & $3.94 \pm 0.19$ & $5.05 \pm 0.18$ & $4.72 \pm 0.22$ & $4.90 \pm 0.14$ & $4.80^{\mathrm{a}} \pm 0.20$ \\
\hline Net gain (g) & $2.88^{\mathrm{e}} \pm 0.11$ & $4.00^{\mathrm{a}} \pm 0.09$ & $3.66^{\mathrm{d}} \pm 0.13$ & $3.85^{\mathrm{b}} \pm 0.14$ & $3.73^{\mathrm{c}} \pm 0.09$ \\
\hline $\begin{array}{l}\text { Weight Gain } \\
(\%)\end{array}$ & $271.69^{\mathrm{d}} \pm 0.09$ & $380.94^{\mathrm{a}} \pm 0.18$ & $345.29^{\mathrm{c}} \pm 0.5$ & $366.67^{\mathrm{b}} \pm 0.04$ & $348.59^{\mathrm{c}} \pm 0.12$ \\
\hline SGR & $2.19^{\mathrm{d}} \pm 0.05$ & $2.62^{\mathrm{a}} \pm 0.04$ & $2.49^{\mathrm{c}} \pm 0.03$ & $2.57^{\mathrm{b}} \pm 0.01$ & $2.50^{\mathrm{c}} \pm 0.02$ \\
\hline FCR & $2.01^{\mathrm{a}} \pm 0.08$ & $1.59^{\mathrm{d}} \pm 0.05$ & $1.63^{\mathrm{d}} \pm 0.03$ & $1.76^{\mathrm{c}} \pm 0.02$ & $1.81^{\mathrm{b}} \pm 0.05$ \\
\hline FCE & $0.50^{\mathrm{d}} \pm 0.03$ & $0.69^{\mathrm{a}} \pm 0.02$ & $0.61^{\mathrm{b}} \pm 0.01$ & $0.56^{\mathrm{c}} \pm 0.02$ & $0.55^{\mathrm{c}} \pm 0.03$ \\
\hline PER & $1.98^{\mathrm{d}} \pm 0.05$ & $2.50^{\mathrm{a}} \pm 0.08$ & $2.45^{\mathrm{b}} \pm 0.02$ & $2.40^{\mathrm{c}} \pm 0.01$ & $2.42^{\mathrm{c}} \pm 0.04$ \\
\hline Survival $(\%)$ & 96 & 98 & 94 & 96 & 92 \\
\hline Men & 96 & 98 & 94 & 96 \\
\hline
\end{tabular}

Mean values are represented as Mean \pm standard error obtained from three replicates. ${ }^{\text {abcde }}$ Mean values having different superscripts in a row differ significantly $(\mathrm{P}<0.05)$. SGR, Specific growth rate; FCR, Feed conversion ratio; FCE, Feed conversion efficiency, PER, Protein efficiency ratio. 
Table.5 Final Carcass composition (\% wet wt. basis) of Mystus cavasius fry at the end of the experiment

\begin{tabular}{|c|c|c|c|c|c|}
\hline Treatments & $\begin{array}{c}\mathrm{C} \\
\text { (Control) }\end{array}$ & $\begin{array}{c}\mathrm{T} 1 \\
\text { (Bactocell) }\end{array}$ & $\begin{array}{c}\mathrm{T} 2 \\
\text { (Bacillus) }\end{array}$ & $\begin{array}{c}\text { T3 } \\
\text { (Levucell) }\end{array}$ & $\begin{array}{c}\mathrm{T} 4 \\
\text { (Mixture) }\end{array}$ \\
\hline Moisture (\%) & $76.56^{\mathrm{a}} \pm 0.43$ & $\begin{array}{c}75.04^{\mathrm{d}} \pm \\
0.45\end{array}$ & $\begin{array}{c}76.23^{\mathrm{b}} \pm \\
0.62\end{array}$ & $\begin{array}{c}76.29^{\mathrm{b}} \pm \\
1.16\end{array}$ & $\begin{array}{c}75.78^{c} \pm \\
0.08\end{array}$ \\
\hline Crude Protein $(\%)$ & $14.89^{d} \pm 0.28$ & $\begin{array}{c}15.68^{\mathrm{a}} \pm \\
0.09\end{array}$ & $\begin{array}{c}15.06^{\mathrm{b}} \pm \\
0.15\end{array}$ & $\begin{array}{c}15.01^{\mathrm{b}} \pm \\
0.50\end{array}$ & $\begin{array}{c}14.98^{c} \pm \\
0.17\end{array}$ \\
\hline Crude Lipid (\%) & $3.20^{\mathrm{d}} \pm 0.11$ & $3.95^{\mathrm{a}} \pm 0.14$ & $3.28^{\mathrm{c}} \pm 0.04$ & $3.25^{c} \pm 0.08$ & $3.34^{\mathrm{b}} \pm 0.05$ \\
\hline Ash (\%) & $3.55^{\mathrm{a}} \pm 0.22$ & $3.47^{\mathrm{a}} \pm 0.34$ & $3.56^{\mathrm{a}} \pm 0.43$ & $3.53^{\mathrm{a}} \pm 0.44$ & $3.60^{\mathrm{a}} \pm 0.09$ \\
\hline
\end{tabular}

Mean values are represented as Mean \pm standard error obtained from three replicates. ${ }^{\text {abcd }}$ Mean values having different superscripts in a row differ significantly $(\mathrm{P}<0.05)$.

Fig.1 Net gain in weight (g) of experimental fishes in different treatments fed with selected probiotics.

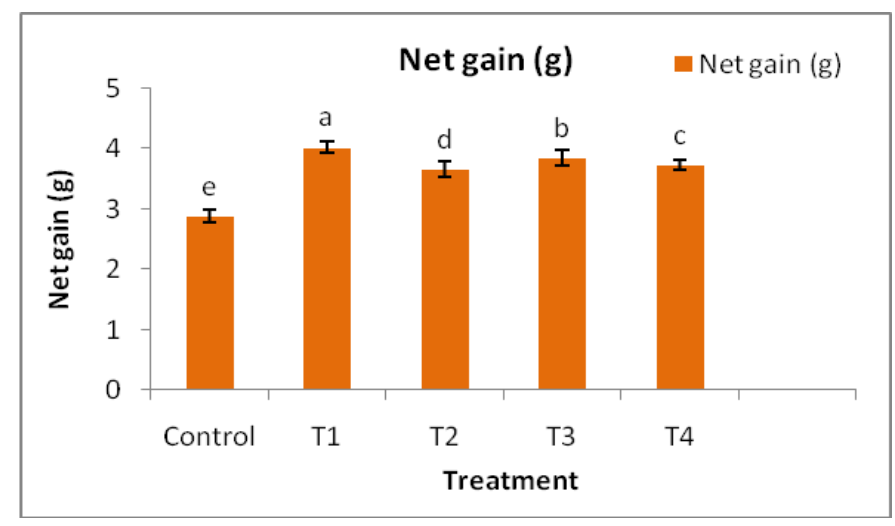

Note: The bars bearing different superscripts vary significantly $(\mathrm{P}<0.05)$; data expressed as mean \pm S.E $(n=3)$.

Fig.2 Weight gain (\%) of experimental fishes in different treatments fed with selected probiotics.

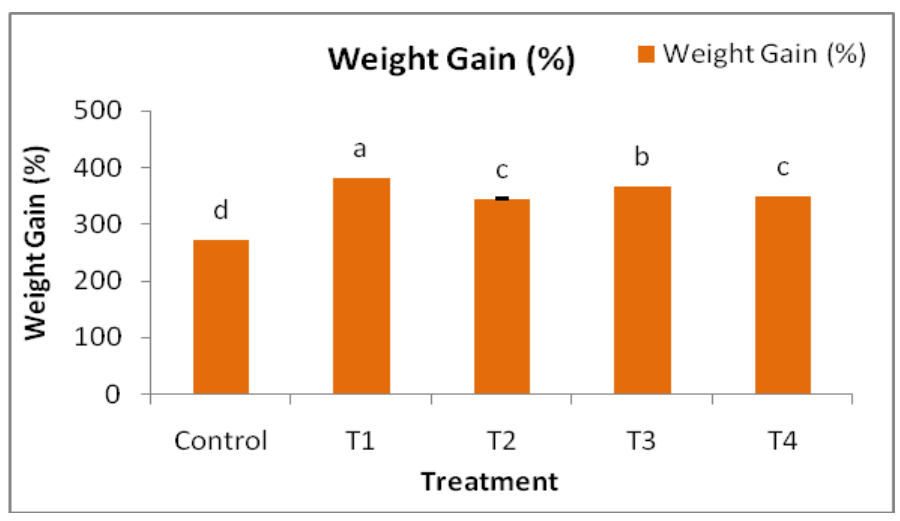

Note: The bars bearing different superscripts vary significantly $(\mathrm{P}<0.05)$; data expressed as mean \pm S.E $(n=3)$. 
Fig.3 Specific growth rate of experimental fishes in different treatments fed with selected probiotics

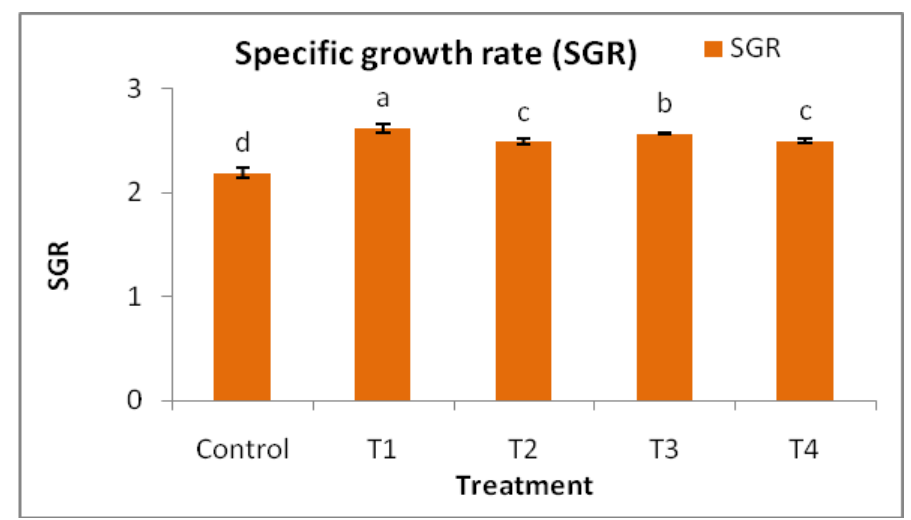

Note: The bars bearing different superscripts vary significantly $(\mathrm{P}<0.05)$; data expressed as mean \pm S.E $(n=3)$.

Fig.4 Feed conversion ratio of experimental fishes in different treatments fed with selected probiotics.

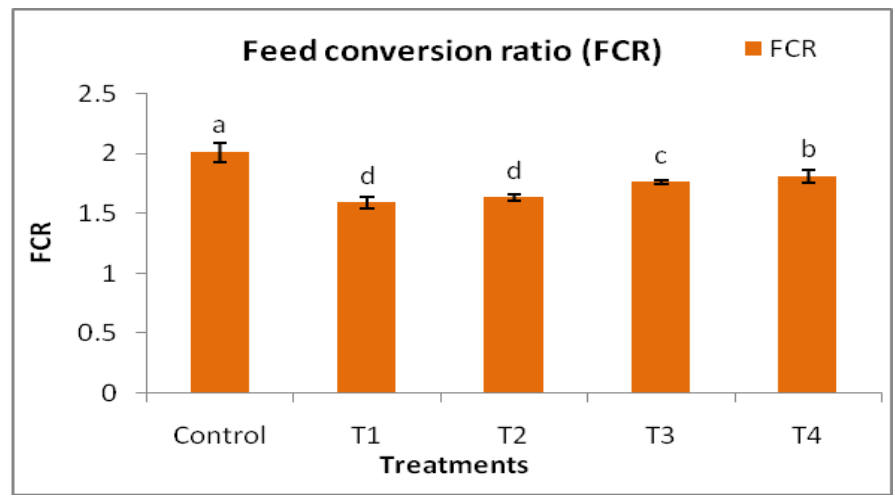

Note: The bars bearing different superscripts vary significantly $(\mathrm{P}<0.05)$; data expressed as mean \pm S.E $(\mathrm{n}=3)$.

Fig.5 Feed conversion efficiency of experimental fishes in different treatments fed with selected probiotics

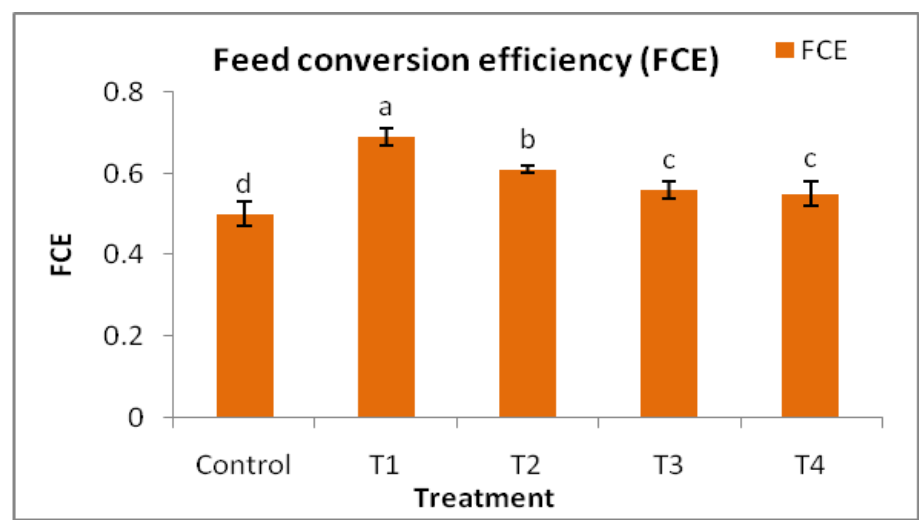

Note: The bars bearing different superscripts vary significantly $(\mathrm{P}<0.05)$; data expressed as mean \pm S.E $(n=3)$. 
Fig.6 Protein efficiency ratio of experimental fishes in different treatments fed with selected probiotics

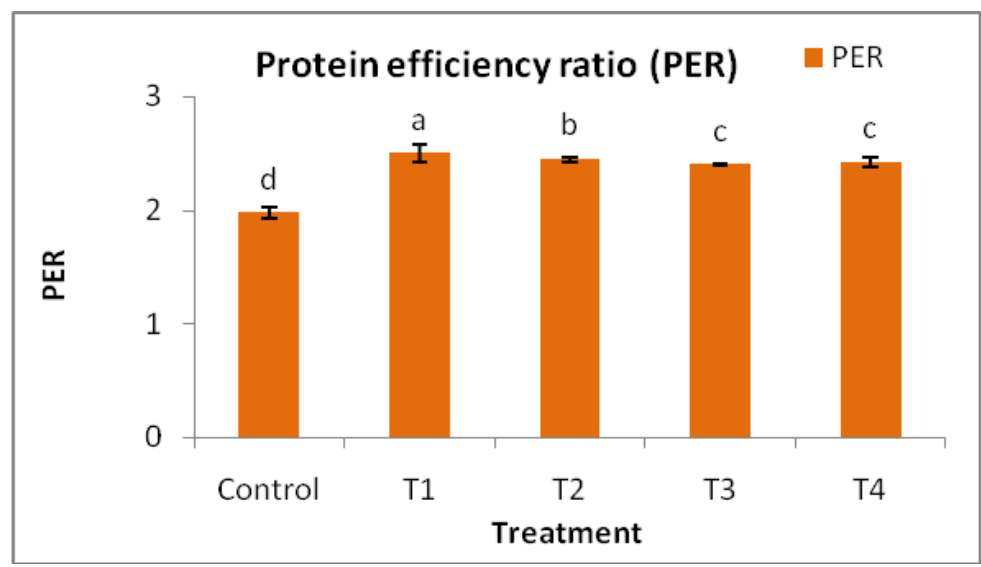

Note: The bars bearing different superscripts vary significantly $(\mathrm{P}<0.05)$; data expressed as mean \pm S.E $(\mathrm{n}=3)$.

The whole body moisture was inversely correlated with body lipids in the present study. Highest crude protein and crude lipid level was observed in T1 group fed with probiotics Bactocell. Body lipid and body moisture were inversely related while body ash contents remained almost constant as reported in previous experiments with African catfish, Clarias gariepinus (Machiels and Henken, 1985; Henken et al., 1986). In the study, fish fed diets containing probiotics supplement showed higher body protein and lipid content than the control diet. The use of probiotics in the diet of Nile tilapia (Oreochromis niloticus) was amended with a probiotic Streptococcus strain, increasing significantly the content of body crude protein and crude lipid in the fish, also weight has increased from $0.154 \mathrm{~g}$ to $6.164 \mathrm{~g}$ in 9 weeks of culture (Lara-Flores et al., 2003).

The results of the feeding trial of $M$. cavasius (gulsha) fry with selected probiotics showed higher growth performance, feed and nutrient utilization than in fish fed the control diet (without probiotic). The growth performance, feed and nutrient utilization were significantly higher in fishes maintained on the diet T1 supplemented with the probiotics Bactocell than in fish fed with other probiotics and the control diet.

From the results of this feeding trial, it is logical to conclude that feed incorporated with the probiotics Bactocell $(0.05 \%)$, can be used as a fish feed in M. cavasius (gulsha) culture, to enhance fish health, better feed efficiency and growth performance. However, further investigations are needed on this under various conditions and probiotics should be made commercially available for aquaculture use at reasonable price.

\section{Acknowledgements}

The authors acknowledge IDRS, BFRI Project for funding of this research from core research programme.

\section{References}

Al-Dohail, M. A., Roshada, H. and Mohammed, A., 2009. Effects of the probiotic, Lactobacillus acidophilus, on the growth performance, haematology parameters and immunoglobulin concentration in African Catfish (Clarias gariepinus, 
Burchell 1822) fingerling. Aquaculture Research, 40: 1642-1652.

AOAC 2005. Official Methods of Analysis, $18^{\text {th }}$ ed. Association of official Analytical Chemists, Washington, DC., USA.

APHA 2005. Standard Methods for the Examination of Water and Wastewater, $21^{\text {st }}$ ed. American Public Health Association, Washington, DC., USA.

Ayoola, S. O., E. K. Ajani. and O. F. Fashae., 2013. Effect of Probiotics (Lactobacillus and Bifidobacterium) on Growth Performance and Hematological Profile of Clarias gariepinus Juveniles. World Journal of Fish and Marine Sciences, 5(1): 1-8.

Balcazar, J. L., De Blas, I., Zarzuela-Ruiz, I., Cunningham, D., Vendrell, D. and Muzquiz, J.L., 2006. The role of probiotics in aquaculture (Review). Veterinary Microbiology, 114: 173186.

Banerjee, S. M., 1967. Water quality and soil condition of fish ponds in some states of India in relation to fish production. Indian Journal of Fisheries, 14: 115119.

Carnevali, O., Vivo, L., Sulpizio, R., Gioacchini, G. I., Olivotto, I., Silvi, S. and Cresci, A., 2006. Growth improvement by probiotic in European sea bass juveniles (Dicentrarchus labrax, L.), with particular attention to IGF-1, myostatin and cortisol gene expression. Aquaculture, 258: 430438.

Denev, S. A., 2008. Ecological alternatives of antibiotic growth promoters in the animal husbandry aquaculture. DSc. Thesis, Department of Biochemistry Microbiology, Trakia University, Stara Zagora, Bulgaria, pp: 294.

Duncan, D.B., 1955. Multiple Range and Multiple F-Test. Biometrics, 11: 1-42.
El-Dakar, A. Y., S. M. M. Shalaby., A. I. Abd Elmonem. and O. M. Wahbi., 2004. Enhancement of performance using fennel seeds meal as feed additive for Nile tilapia Oreochromis niloticus. Journal of Egyptian Academic Society of Environmental Development, 5: 4367.

Fuller, R., 1989. Probiotic in man and animals. Journal of Applied Bacteriology, 66: 365-378.

Fuller, R., 1992. History and development of probiotics. In: Probiotics: The Scientific Basis (Fuller, R. ed.), Champman and Hall, London, England, pp: 1-18.

Hardy, R. W., 1995. Current issues in Salmonid Nutrition In: Lim C.E. and D.J. Sessa (Eds.). Nutrition and Utilization Technology Aquaculture. AOCS press, Champaign, IL, USA, pp: 26- 50. Document ID: 3936.

Henken, A. M., Machiels, M. A. M., Dekker, W. and Hogendoorn, H., 1986. The effect of dietary protein and energy content on growth rate and feed utilization of the African catfish, Clarias gariepinus (Burchell 1822). Aquaculture, 58(1-2): 55-74.

Hepher, B., 1988. Requirement for protein. Nutrition of pond fishes. Cambridge: Cambridge University Press, pp.175-216.

Lara-Flores, M., Olvera-Novoa, M. A., Guzmal n-Mepndez, B. E. and Lonpez-Madrid, W., 2003. Use of the bacteria Streptococcus faecium and Lactobacillus acidophilus and the yeast Saccharomyces cerevisiae as growth promoters in Nile tilapia (Oreochromis niloticus). Aquaculture, 216: 193-201.

Li, P. and D. M. Gatlin III., 2004. Dietary brewer's yeast and the probiotic Grobiotic TM AE influence growth performance, immune responses and 
resistance of hybrid striped bass (Monrone chrypsops X M. saxatilis) to Streptococcus iniae infection. Aquaculture, 231: 445-456.

Machiels, M. A. M. and Henken, A.M., 1985. Growth rate, feed utilization and energy metabolism of the African catfish, Clarias gariepinus (Burchell, 1822), as affected by dietary protein and energy content. Aquaculture, 44(4): 271-284.

Marzouk, M. S., M. M. Moustafa. and N. M. Mohamed., 2008. The influence of some probiotics on the growth performance and intestinal microbial flora of Oreochromis niloticus. Proceedings of the $8^{\text {th }}$ International Symposium on Tilapia in Aquaculture, Cairo, Egypt, pp: 1059-1071.

Mohamed, K. A., Badia, Abdel, Fattah. and A. M. S. Eid., 2007. Evaluation of using some feed additives on growth performance and feed utilization of monosex Nile tilapia (Oreochromis niloticus) fingerlings. Agricultural Research Journal, 7(3): 49-54.

Moriarty, D. J. W., 1996. Microbial biotechnology: a key ingredient for sustainable aquaculture. Infofish International, 4: 29-33.

Noh, S. H., Han, K., Won, T. H. and Choi, Y. J., 1994. Effect of antibiotics, enzyme, yeast culture and probiotics on the growth performance of Israeli carp. Korean Journal of Animal Science, 36: 480-486.

Reid, G. J., Jass, M. T. Sebulsky. and K. J.
McCormick., 2003. Potential uses of probiotics in clinical practice. Clinical Microbiology Reviews, 16(4): 658672.

Sapkota, A., A. R. Sapkota., M. Kucharski., J. Burke., S. McKenzie., P. Walker and R. Lawrence., 2008. Aquaculture practices and potential human health risks: current knowledge and future priorities. Intrnational, 34(8): 12-15.

Suzer, C., Coban, D., Kamaci, H. O., Saka, S., Firat, K., Otgucuogfllu. and $\mathrm{K}^{`} \mathrm{c}^{`}$ ksari, H., 2008. Lactobacillus spp. bacteria as probiotics in gilthead sea bream (Sparus aurata, L.) larvae: effects on growth performance and digestive enzyme activities. Aquaculture, 280: 140-145.

Tovar-Ramrez, D., Zambonino, I. J., Cahu, C., Gatesoupe, F. J. and VaLzquezJuaLrez, R., 2004. Influence of dietary live yeast on European sea bass (Dicentrarchus labrax) larvae development. Aquaculture, 234: 415427.

Wang, Y. and Zirong, X., 2006. Effect of probiotics for common carp (Cyprinus carpio) based on growth performance and digestive enzyme activities. Animal Feed Science and Technology, 127: 283-292.

Yanbo, W. and Zirong, X., 2006. Effect of probiotics for common carp (Cyprinus carpio) based on growth performance and digestive enzyme activities. Animal Feed Science and Technology, 127: 283-292.

\section{How to cite this article:}

Zulfikar Ali, Md., Mritunjoy Paul, Prasanta Jana, Md. Khalilur Rahman and Yahia Mahmud. 2018. Evaluation of Selected Dietary Probiotics on Growth Performance, Nutrient Utilization and Body Carcass Composition of Mystus Cavasius (Hamilton, 1822) Fry. Int.J.Curr.Microbiol.App.Sci. 7(08): 3328-3339. doi: https://doi.org/10.20546/ijcmas.2018.708.356 